\title{
From the economic to the social contribution of the Social Economy. Monetary assessment of the social value created for the Spanish economy
}

\author{
R. Belén Castro \\ Rosa Santero \\ M. Isabel Martínez \\ Paula De Diego
}

ABSTRACT: The role of the Social Economy (SE) in society is increasingly acknowledged by social agents and institutions, especially in the context of the 2030 Agenda for Sustainable Development. Commitment to SE requires the support of quantitative measurement of its contribution to society from an aggregate perspective. The difficulty in specifying it in quantitative terms is related to the assessment of the contribution of SE's differentiating and intrinsic values. These values contribute to the fight against some structural problems that persist in modern society in terms of unemployment, inequality, territorial imbalance, environmental problems and social exclusion that surpass the economic sphere and involve the contribution to social goals, social utility and social and territorial cohesion. Our objective is an assessment in quantitative terms, including an estimation, in monetary terms, of the specific contribution of Social Market Economy (SMkE) firms to society linked to their distinctive principles, and thus their behaviour, in comparison to traditional profit-oriented firms, used as a control group. We use impact analysis techniques, with a simulation exercise, by which SMkE entities "lose" their identity and behave like profit-oriented firms. The results obtained for Spain confirm the existence of differential behaviour that generates social value in several ways. In monetary terms, in 2017, SMkEs contributed 6,229 million Euros in benefits to Spanish society that would have been lost if SMkE entities had behaved like profit-oriented firms.

KEYWORDS: Social Economy, Social Utility, Socioeconomic Impact, Social Cohesion Territorial Cohesion, Sustainable Development.

ECONLIT CODES: B55, J81, P13, Q01, R11.

How to cite this article/Cómo citar este artículo: CASTRO, R.B., SANTERO, R., MARTÍNEZ, M.I. \& DE DIEGO, P. (2020): "From the economic to the social contribution of the Social Economy. Monetaryassessment of the socialvaluecreated for the Spanish economy.", CIRIEC-España, Revista de Economía Pública, Socialy Cooperativa, 100,31-65. DOI: 10.7203/CIRIEC-E.100.18163.

Correspondence: R. Belén Castro, Universidad Rey Juan Carlos, belen.castro@urjc.es, ORCID: 0000-00029098-0748; Rosa Santero, Universidad Rey Juan Carlos, rosa.santero@urjc.es, ORCID: 0000-0002-1071-4280; M.Isabel Martínez, Abay Analistas, mmartinez@abayanalistas.net, ORCID: 0000-0002-4912-1351; Paula De Diego, Abay Analistas, pdediego@abayanalistas.net, ORCID: 0000-0002-3475-1967. 


\section{Resumen extendido}

\section{Mas allá de la aportación económica de la Economía Social. Cuantificación del valor social creado para la economía española.}

\section{Objetivo}

La Economía Social tiene cada vez mayor presencia en el debate político, no solo a nivel nacional sino también internacional, en especial en el contexto de la Agenda para Desarrollo Sostenible 2030 de Naciones Unidas. De igual forma, la Unión Europea reconoce su contribución al desarrollo económico, social y humano y la considera un motor de la transformación de las sociedades, los sistemas de bienestar social y las economías contemporáneas.

A pesar de este creciente reconocimiento, la Economía Social encuentra limitaciones significativas a la hora de visibilizar su aportación a la sociedad, que se deben tanto a la falta de estadísticas que reflejen adecuadamente su actividad como al hecho de que esta aportación supere los límites del ámbito económico y se adentre en el concepto de bienestar o utilidad social, concepto de mayor complejidad, especialmente en lo que a su medición cuantitativa se refiere. Aunque en las últimas décadas se ha registrado un aumento importante de la literatura académica dedicada a la medición del impacto de la Economía Social, una buena parte de la misma se refiere a determinados tipos de entidades (cooperativas en su mayoría) y se apoya en análisis de tipo cuantitativo a nivel micro, esto es, de empresas, no siendo suficientes las mediciones cuantitativas a nivel macro, para el conjunto del país.

El objetivo de este estudio es la cuantificación, y monetarización, de la contribución diferencial que el conjunto de las entidades que forman la Economía Social de Mercado realiza a la sociedad ${ }^{1}$. La tesis de partida de este análisis de impacto se concreta en que los principios que propugna la Economía Social motivan un comportamiento diferencial de sus empresas y entidades en relación con la composición de sus plantillas, las condiciones de trabajo, su especialización productiva y su ubicación geográfica. Este comportamiento diferencial constituye, a su vez, una importante aportación a la cohesión social y territorial, que excede la aportación valorada de forma tradicional a través de variables macroeconómicas y, que se adentra en el concepto de utilidad social. La cuantificación de dicha utilidad social y su valoración en términos monetarios constituye un aspecto crucial en la visibilización de la aportación de la Economía Social, y en particular de la Economía Social de Mercado, a la sociedad.

1. Este Trabajo es parte de un proyecto de investigación financiado por la Confederación Empresarial Española de Economía Social (CEPES). Los resultados de dicho proyecto pueden ser consultados en:

https://www.cepes.es/files/publicaciones/118.pdf 


\section{Metodología}

La metodología empleada se basa en el uso de técnicas cuasi-experimentales con contrafactuales, cuyos resultados se combinan en una metodología propia diseñada para la valoración monetaria de la contribución de la Economía Social. Dicha valoración monetaria se obtiene partiendo de una identificación de los diferentes agentes o stakeholders que van a experimentar algún tipo de impacto por la actividad de estas empresas y entidades. En concreto, se utiliza una metodología diseñada en tres fases.

La primera de estas fases consiste en la identificación y descripción de los efectos de utilidad social generados por las entidades de Economía Social en términos de cohesión social y territorial, constituyendo el marco conceptual donde se revisan y actualizan los resultados obtenidos en un trabajo previo (Martinez et al., 2013).

En la segunda fase se realiza una medición del comportamiento diferencial de las entidades de Economía Social de Mercado mediante una metodología de análisis de impacto. Así, nuestra hipótesis principal de trabajo es que las entidades de Economía Social de mercado se comportan de manera diferencial con respecto a un grupo de control (sociedades anónimas y limitadas), de economía mercantil orientadas a la obtención de beneficios económicos.

Por último, en la tercera fase, se aplica una metodología ad hoc para cuantificar en términos monetarios el diferencial identificado en la fase anterior en relación al empleo y sus condiciones laborales.

La delimitación de las entidades de Economía Social de Mercado parte de la Ley de Economía Social 5/2011 y utiliza la diferenciación en función del destino final de su actividad (Economía Social de Mercado y de no mercado). En este trabajo nos centraremos en las entidades que forman parte de la Economía Social de Mercado y que incluyen cooperativas, mutualidades, sociedades laborales, centros especiales de empleo, sociedades de transformación agraria, cofradías de pescadores y empresas de inserción, lo que nos permite tener una visión específica de su contribución a la actividad económica en términos de desarrollo sostenible, frente a las entidades tradicionales enfocadas a la obtención de beneficio económico. La base de datos utilizada es la Muestra Continua de Vidas Laborales (publicada anualmente por el Ministerio de Trabajo y Economía Social) en su edición de 2018, con datos para 2017. En la muestra final se han identificado 4.452 entidades de Economía Social de Mercado y 13.688 trabajadores ocupados en estas empresas, y para el grupo de control (SA y SL) se cuenta con 4.445 empresas y 13.913 trabajadores.

\section{Resultados}

Los resultados obtenidos confirman la existencia de un comportamiento diferencial generador de valor social de la Economía Social de Mercado a través de la creación de un empleo inclusivo, de mayor estabilidad, con menor dispersión salarial, con mayores niveles de igualdad en las empresas a todos los niveles, y con una ampliación de la oferta privada de servicios sociales y de educación. 
Además, las empresas de Economía Social de Mercado contribuyen significativamente a la cohesión territorial, ubicándose en mayor medida en zonas rurales y ciudades intermedias (municipios menores de 40.000 habitantes) y mejoran la competitividad de las economías rurales a través del desarrollo de determinadas ramas de actividad, que o bien permiten un mejor aprovechamiento de las potencialidades, o bien acercan una oferta de servicios que son vitales para frenar la pérdida de población.

En términos monetarios, la Economía Social de Mercado aporta 6.229 millones de euros anuales en beneficios a la sociedad, 3.930 millones de euros anuales en retribuciones para colectivos de difícil empleabilidad y 1.770 millones de euros anuales en prestaciones para las Administraciones Públicas.

Por agentes, los principales beneficiarios son los colectivos con mayores dificultades de acceso al empleo, que perciben 3.930 millones de euros anuales en sueldos. En segundo lugar, está la Administración Pública, con 1.770 millones de euros anuales de beneficios directos e indirectos y, finalmente, las propias empresas, que obtienen un beneficio neto de unos 528 millones de euros anuales.

Todos estos beneficios, que ascienden en total a 4 billones de euros anuales, no existirían si las actividades fueran realizadas por empresas orientadas al beneficio económico. De hecho, este resultado puede tomarse como un umbral inferior, debido a las dificultades encontradas para a valoración de ciertos efectos, como los de naturaleza intangible. En este sentido, este trabajo confirma el aporte de la Economía Social en términos del valor social generado, con un impacto positivo en la cohesión social y territorial, objetivos implícitos de una agenda de crecimiento inclusivo y sostenible, con un enfoque de crecimiento centrado en las personas.

\section{Valor original / Contribución}

Este trabajo contribuye a la literatura desde una doble perspectiva. En primer lugar, valora de forma conjunta la aportación de todas las empresas de la Economía Social de Mercado, con independencia de su forma jurídica, frente a los trabajos existentes, enfocados a un grupo específico de entidades. Y en particular, el análisis de las entidades de Economía Social de Mercado permite una valoración de la contribución específica al desarrollo económico sostenible, en línea con los ODS, frente a la actividad desarrollada por empresas mercantiles tradicionales. En segundo lugar, el trabajo contribuye a la literatura desde una perspectiva metodológica, al aplicar técnicas contrafactuales de análisis de impacto, y abordar la valoración monetaria de una parte significativa de los efectos contrastados a nivel empírico; es decir, una vez medidos esos efectos se calcula su valor monetario para avanzar, aportando un nuevo plano, en la visibilización de la contribución de la Economía Social al conjunto de la sociedad.

Palabras clave: Economía Social, Utilidad Social, Impacto socioeconomico, Cohesión Social, Cohesión territorial, Desarrollo Sostenible. 


\section{Introduction}

The role of the Social Economy (SE) in society is being increasingly acknowledged by social agents and institutions, especially in the context of the 2030 Agenda for Sustainable Development and the Sustainable Development Goals (SDG) included in it (Castro, Bandeira and Santero-Sánchez, 2020; Chaves-Avila and Gallego-Bono, 2020; Mozas-Moral, Bernal-Jurado, Fernández-Uclés and Medina-Viruel, 2020; Villalba-Eguiluz, Egia-Olaizola and Pérez de Mendiguren, 2020). In this sense, the commitment of SE values to SDGs is clear from a conceptual point of view, but it requires the support of quantitative measurement of its contribution to society. One of the main challenges in the assessment of that contribution in quantitative terms is the difficulty in specifying the contribution of the differentiating, intrinsic values that characterize SE entities. These have an influence beyond the economic sphere and involve contributions to social welfare and social utility, which are extremely complex concepts, especially in terms of measurement. This challenge is complicated by the lack of adequate statistics, both from a conceptual and disaggregation perspective.

In this regard, the use of traditional economic measurements, developed to analyse the contribution of profit-oriented firms by focusing on the direct impact on macroeconomic variables, explicitly underestimates the real global effect of SE entities on society, a crucial limitation to making their contribution to society visible. Moreover, it shifts the focus from the main contribution of SE compared to traditional profit-oriented firms. SE contributes to the fight against some structural problems that persist in modern society in terms of unemployment, inequality, territorial imbalance, environmental problems and social exclusion (Ben-Ner, 2018; Tomás Carpi, 2008; Valiente, 2019). SE shows resilience in times of crisis, increasing the stability of jobs (Birchall and Ketilson; 2009; Borzaga, Salvatori and Bodini, 2017; Diaz and Marcuello, 2010; Monzon and Chaves, 2016), and their entities show a higher quality of employment based on some critical dimensions of employment such as gender equality, flexibility, safety, inclusion, diversity and non-discrimination (Calderón and Calderón, 2012; Castro et al,,2020, Martinez-Leon, Olmedo-Cifuentes, Martínez-Victoria and Arcas-Lario, 2020; Meliá-Martí, Tormo-Carbó and Juliá-Igual, 2020; Santero and Castro, 2016).

Although an important increase in academic literature devoted to the measurement of the impact of SE has been registered in recent decades, a good part of it concerns a particular kind of entity, or is grounded in qualitative analysis, quantitative measurements being very scarce, especially in terms of SE aggregated contribution. In this context, the objective of this paper is to obtain a quantitative assessment, including an estimation in monetary terms, of the specific contribution of SE entities to society linked to their distinctive principles in comparison to the behaviour of traditional profit-oriented firms. To this end, we reviewed and updated our previous theoretical work (Martínez, Castro, Alemán, Guilló and Santero, 2013) identifying and describing the effects on territorial and social cohesion in terms of social utility.

Specifically, we designed a three-step methodology, in which we address particular questions regarding the socioeconomic contribution of the principles that characterize SE entities at each stage: 
1) First stage: Identification and description of the effects of the social utility generated by SE entities in terms of social and territorial cohesion. Do SE entities exhibit different behaviour to profit-oriented firms? How can those differences be assessed? This constitutes our conceptual framework, where we review and update our previous theoretical work (Martinez et al., 2013) identifying and describing the effects in terms of social utility upon territorial and social cohesion.

2) Second stage: Assessment of differential behaviour. Are there significant differences? How do these differences affect society? Once the differences are conceptually defined, we conduct an impact analysis methodology. Our working hypothesis is that SE shows differences in comparison to the control group (profit-oriented firms) in terms of the differences identified in the previous stage.

3) Third stage: Monetary assessment. Can the previous assessment be translated into monetary units? In this stage, we apply an ad hoc methodology to translate the differences identified in the previous stage in terms of employment and labour conditions into monetary terms.

This study contributes to the existing literature in two ways. Firstly, while the literature tends to focus on specific entities such as cooperatives and NGOs, this work uses the current legal definition of SE in Spain, approved by Law 5/2011, a broad delimitation of SE in line with the international conceptual definition of Social Economy. Moreover, this work also takes into account an economic perspective in the conceptualization of SE. From an economic perspective, these entities can be grouped, in terms of the final destination of their goods and services, into Social Market Economy (throughout the text we will use the acronym SMkE) and Social Non-market Economy (EESC, 2016, pp.14). The first group includes all companies and entities described above except associations and foundations, which are part of the Social Non-market Economy group. The focus on SMkE allows us to have a clearer understanding of the mechanisms through which SE contributes to sustainable development as a change-maker agent in the economic system, in comparison with traditional profit-oriented firms, prioritizing people and communities over profits (Chavez and Gallego-bono, 2020).

Secondly, the methodology used for assessment and monetary quantification contributes to the existing literature with the quantification of the social impact of these entities. The use of a simulation exercise by which SE entities "lose" their identity and, thus, the social value associated with them and behave like traditional profit-oriented firms, stresses the key role of SE in the inclusion of the 2030 Agenda for Sustainable Development Goals in national policies. The results presented should be used together with traditional assessment methodologies to fully capture the role of SE entities, which is otherwise underestimated.

Spain is used for practical application of the methodology developed, as it is a country with a Social Economy tradition whose size provides statistically significant results and data to conduct the methodology developed.

The remaining of the paper is organized as follows. Firstly, the theoretical framework and a review of SE impact are presented. Then, the paper shows the methodological development, 
including a description of the dataset used. The results are shown according to methodological phases. The paper concludes with a set of conclusions and policy recommendations.

\section{Theorical framework and literature review}

\subsection{The contribution of SE beyond economic terms}

Social Economy entities share some common denominators regarding their ethical principles, organizational values, objectives and characteristics. A deeper analysis of these denominators is beyond the scope of this paper, but it is commonly agreed that entities pertaining to SE have the ultimate goal of the generation of social value, instead of the distribution of economic profit. This particular characteristic makes it difficult to use traditional variables (both from a microeconomic and macroeconomic perspective) to fully measure the contribution of these entities to society.

The concept of social utility, also expressed in other terms such as "social value" and "social profitability", has been subject to continuous reinterpretations (Guzman, Santos and Barroso, 2020; Rodet, 2008). In fact, the terms "social impact", "social value creation" and "social return" are frequently interchanged both in the academic world and among professionals (Maas and Liket, 2011). Public Health England (2015: 74) states that, "social value is the additional benefit to the community from a commissioning/procurement process over and above the direct purchasing of goods, services and outcomes". The concept of social impact includes all the social and cultural consequences for the community of any public or private action which changes the way people live, work, interact and organize themselves in order to satisfy their needs as members of society (Dufour, 2015).

From an applied and multidimensional point of view, Gadrey (2006) considers social utility to be the activity of Social Economy entities whose objective is to contribute to the reduction of social and economic inequalities, fostering solidarity and sociability and contributing to the improvement of group conditions in terms of education, health, culture, environment and participation in society. This concept of social utility is related to the collective need to prevent and fight against the different social forms of discrimination, inequality, marginalisation and exclusion and translates into social and territorial cohesion. A socially cohesive community supposes a global situation in which citizens share a sense of belonging and inclusion, participate actively in public matters, recognise and tolerate differences, as well as enjoy relative equity in the access to public utilities and goods. In turn, territorial cohesion "is the process of promoting a more cohesive and balanced territory, by: (i) supporting the reduction of socioeconomic territorial imbalances; (ii) promoting environmental sustainability; (iii) reinforcing and improving territorial cooperation/governance processes; and (iv) reinforcing and establishing a more polycentric urban system" (Medeiros, 2016: 10). In short, it can be defined as 
the balanced distribution of human activities within the territory, completing social and economic cohesion.

Therefore, the contribution of SE principles to society can be approached from a quantitative perspective focusing on their contribution to social value creation in terms of social and territorial cohesion. A review of the theoretical and applied literature regarding social utility and the role of SE entities in society allows us to identify major dimensions of social and territorial cohesion categories: the reduction of labour and income inequalities; the promotion of sustained, inclusive and sustainable economic growth; full and productive employment and decent work; creation of economic activity and employment in rural areas; the competitiveness of the rural economy and retention of the rural population.

Likewise, the development of methodologies that supplement the economic and financial impact are crucial to contribute to the visibility of the differential contribution of these entities to the economy and society in comparison to the activity carried out by other types of entities, especially compared to traditional, mainstream, profit-oriented firms.

\subsection{Analysis of the impact of SE on society}

The positive impact of SE entity principles has been widely discussed in the literature, but the difficulty of translating them into quantifiable and valuable effects has limited the theoretical approach. The main challenges to assessing the impact of these principles are focused on the design of an appropriate methodological approach and on the lack of statistical information about SE.

From an individual firm perspective, there is a growing interest in understanding the impact of organizations beyond their economic results and capture other important factors such as their contribution to human welfare and environmental sustainability, points that are not included in traditional purely economic and financial indicators (Barraket and Yousefpour, 2013; Duguid, 2017).

At a company level, different tools have been developed to measure non-financial impact and to inform society about them (Brown, Hicks and Leclerc, 2015; Christianson, 2015; Duguid, 2017; Hough, 2015). For example, there is an important development of reports referring to non-financial impacts: sustainability, corporate social responsibility (CSR) and environmental, social and governance (ESG) influences, among others. This effort is part of the interest in understanding the global impact of an organization, especially for those that do not have market economy activity (associations, foundations, NGOs...), such as SE firms, which have characteristic values that prioritize people (social impact) over capital (economic impact). For this reason, these entities should be potential users of non-financial indicators that show the impact, beyond economic results, in terms of social and/or environmental influences.

Despite general interest in expanding the characterization and evaluation of firms beyond the economic perspective, the efforts have remained mostly at a firm perspective, with few attempts to develop strategies to obtain aggregated indicators that permit an assessment of the global contribution of SE entities. In this regard, the main advances are focused on cooper- 
atives. The World Co-operative Monitor (Duguid, 2017) has presented an interesting approach to developing a multidimensional database that provides information about socioeconomic value and the impact of cooperatives, both in a global scenario and in regional and state contexts.

In parallel to the mentioned development of tools and indicators, impact analysis methodologies traditionally used for the analysis of public policies, have also been used to develop strategies for the assessment of the SE's contribution to society from a global perspective. An important part of this literature is framed within the New Public Management (NPM) paradigm (Duguid, 2017; Retolaza, San-José and Ruíz-Roqueñi, 2015). Conceptually, impact assessment of an entity is obtained when we compare its current situation with what would have occurred if the services of this entity had not been provided. Measurement of these effects is frequently carried out with statistical techniques linked to impact analysis with counterfactuals (Manetti, 2014).

The literature shows two main trends in social impact measurement, in general, and in SE and the third sector in particular (Gibbon and Dey, 2011): one of them is focused on Social Accounting and Auditing (SAA) and the another one, on Social Impact Assessment (SIA). Regarding SAA, Gray (2000) includes in this approach, "... the preparation and publication of an account about an organisation's social, environmental, employee, community, customer and other stakeholder interactions and activities and, where, possible, the consequences of those interactions and activities. The social account may contain financial information but is more likely to be a combination of quantified non-financial information and descriptive, non-quantified information." (Gray, 2000: 250). SSA related methodologies have been broadened and organizations have developed tools for its measurement, such as the Global Reporting Initiative (GRI) created in 1997. In its traditional form, SSA continues to be used worldwide but has lost part of its momentum, especially with the development of SIA methods such as Social Return on Investment (SROI) (Gibbon and Dey, 2011; Dufour, 2015).

Focusing on SIA, this approach is defined by the International Association for Social Impact Assessment as "an assessment that includes processes of analysis, monitoring and management of social consequences, intentional and not intentional, both positive and negative, of planned interventions (policies, programmes, plans and projects) and any social change process invoked by that intervention whose main aim is to achieve a more sustainable and equal biophysical and human environment" (Vanclay, 2003, p.6).

This methodology, originally developed by Campbell in 1957, is used in the third sector (Dufour, 2015; Retolaza et al., 2015). George G. Robers, who is considered the pioneer in the introduction of this approach, documented his method in a publication called Social Return on Investment Approach (Dufour, 2015: 6). This is the approach that has won more ground in the last decade, contributing to the spread of social assessment measurement in the third sector, as it acknowledges that the activity of these organizations spreads to a complex network of stakeholders and agents (Arena, Azzone y Bengo, 2015; Arvidson, Lyon, McKay and Moro, 2013).

Concurrently, some scholars have been working on a holistic approach to value creation, promoting a new mixed concept defined as Blended Value Accounting (BVA), which seeks to not decouple the value and social impact from financial-economic results generated by an economic 
activity. The logic of this analysis suggests, firstly, that all organizations generate both financial and social value and, secondly, that both kinds of value generation are intrinsically connected instead of being opposites in a zero-sum equation (Manetti, 2014). Thus, whenever possible and appropriate, monetary measures should be sought to estimate the economic and social impact.

Furthermore, although measurement is intended to be carried out in qualitative or quantitative terms, a clear trend towards quantification exists that associates the impact with a numerical value (Dufour, 2015).

In Spain, Retolaza et al. (2015) developed a social accountancy and social value estimation model based on stakeholders that permits adding social value, in its monetary form, using accounting standards. These authors did not find it possible to carry out a complete monetary quantification of social value with this model, but it does show economic value with social impact, socioeconomic profitability and specific social value. Thereby, social value indicators are translated into economic-financial parameters. The authors analyse the effects of the social value associated with two SE entities in the Basque Country, Lantegi Batuak and Municipal Housing of Bilbao ("Viviendas Municipales de Bilbao"), although they leave the quantification of their effects pending. Retozala et al. model for social accountancy has been used to design specific indicators to contribute to the quantification of the socioeconomic impact generated by entities pertaining to social economy, such as cooperatives (Etxezarreta, Mendiguren, Díaz and Errasti, 2018) and agricultural processing companies (Román, Guzmán, Mendoza and Pérez, 2020).

In terms of aggregate assessment, a pioneering work in the value measurement of these principles was developed by Martínez et al. (2013). In their work, the authors identify different social effects by agents and stakeholders and quantify them, using a counterfactual measurement methodology by grouping these effects into two dimensions: territorial and social cohesion. This work includes, for the first time, a monetary quantification of the value of SE entities, making the creation of social value visible within the sector and emphasizing it to political decision makers.

Therefore, the work presented in this paper is focused on a macroeconomic impact analysis, following the line developed by Martínez et al. (2013), adjusting SE definition to the one approved by Law 5/2011 and considering a Social Market Economy institutions perspective, besides the revision of technical aspects of the methodology, especially in the identification of the different types of SE entities from an applied perspective.

\section{Methodology and database}

\subsection{Database}

The delimitation of the SE in Spain is based on the definition in Law 5/2011 of Social Economy and those used by the scientific association CIRIEC-SPAIN and the Spanish Business Confederation of Social Economy (CEPES) and includes: Cooperatives, mutual benefit societies, 
employee-owned companies, sheltered work centres, agricultural processing companies, fishermen's associations, and associations and foundations. Social Economy activity can be classified in terms of the final destination of the goods and services produced in two sub-sectors: market oriented and non-market oriented activity. Following EESC (2016) we consider associations and foundations to be non-market oriented entities in terms of their activity, while we consider that the rest of the mentioned entities conduct market oriented activities. In this paper we focus on market-oriented entities as the methodology is based on employment characteristics and volunteers represent an important share of the human resources involved in non-market oriented entities, and thus, are left aside in employment and related statistics introducing distortions that require further development in the methodology ${ }^{2}$. The database used for the Spanish case is the Continuous Sample of Working Histories (CSWH), published by the Spanish Ministry of Labour and Social Economy on a yearly basis. The CSWH contains information about a representative sample (4\%) of the population registered with the Social Security administration during the sampling year, 2017 in our case, including active workers and recipients of unemployment benefit, among others. The final sample for market-oriented activities was 4,452 firms and 13,688 employees, while the control group was formed by 4,445 firms and 13,913 employees. Besides this original sample, we used two sub-samples. Firstly, due to data restrictions we used a subsample for wage analysis as wage data in CSWH are obtained from tax data reported by employees in the common tax regime, which includes Spain except the Basque Country and the Navarre region. The wage subsample includes data for full-time employees, working the whole of 2017: 7,202 SMkE workers and 7,400 CG workers. Secondly, the analysis of working lives during the period 2009-2017 entailed identifying SMkE workers that had always been employed by SMkE firms (or with unemployment episodes) to have a pure SMkE working life to compare with a control group of workers always employed by CG firms. The subsample has information for 9,553 SMkE workers and 9,659 CG workers. To conduct the territorial cohesion perspective, we defined those with a population of less than 40,000 as "rural areas and medium-sized cities". Due to database restrictions there was no availability of more disaggregated data, which constituted a limitation to identifying areas (municipalities) traditionally considered as rural in the literature.

Graph 1 shows the relevance of cooperatives (71\%) and, although to a lower extent, sheltered employment centres (15\%), in the sample obtained, in line with their key role in SE in Spain.

2. The complexity of the evaluation of volunteer work is discussed in the literature; see for instance Arvidson et al. (2013). 


\section{Graph 1. Spanish SMkE entities by organizational type, 2017}

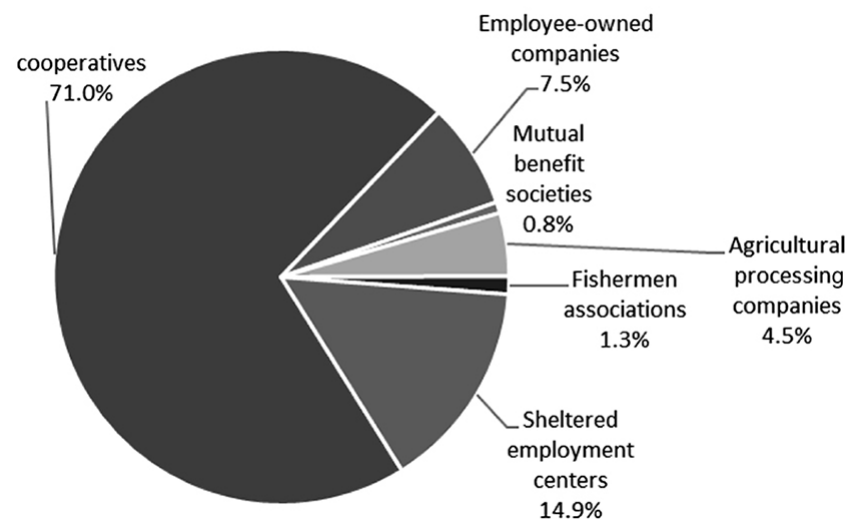

Source: Continuous Sample of Working Histories (2017) and own calculations.

A second, important characteristic of market oriented SE organizations is their large average size. While $48 \%$ of profit-oriented firms in the sample had only 1 to 10 workers, this proportion fell to $41,8 \%$ for SE organizations. On the other hand, the proportion of medium and large firms was higher in the SE (see Table 1).

Table 1. Distribution of SMkE firms by size. Percentage of the total, 2017 Size (no workers) Percentage

\begin{tabular}{lr}
\hline Micro (1-10) & $41.8 \%$ \\
\hline Small $(11-50)$ & $38.1 \%$ \\
\hline Medium (51-250) & $16.6 \%$ \\
\hline Large $(+250)$ & $3.6 \%$ \\
\hline Total & $100 \%$
\end{tabular}

Source: Continuous Sample of Working Histories (2017) and own calculations.

One of the key issues in the analysis of the SE is its specialization in terms of industry. In this regard, even though the construction of the counterfactual analysis ensures having comparable groups, controlling for size of firm and industry, it is important to bear in mind the distribution of employment in the SE. Table 2 shows the distribution of employees working in SMkE entities, showing that in terms of employment the key sectors were related to social 
activities, including social work, education and health care services. However, employment is to some extent distributed between other sectors like business-related services, trade, manufacturing and agriculture.

\section{Table 2. Distribution of employees by industry in SMkE firms. Percent- age of the total. 2017}

\begin{tabular}{lr} 
Industry & Percentage \\
\hline Agriculture, forestry and fishing & $11.9 \%$ \\
\hline Manufacturing & $16.1 \%$ \\
\hline Energy, water supply, waste management & $0.3 \%$ \\
\hline Construction & $4.6 \%$ \\
\hline Wholesale and retail trade, and personal services* & $24.8 \%$ \\
\hline Transport, storage and post services & $3.5 \%$ \\
\hline Accommodation and Food Service Activities & $3.0 \%$ \\
\hline Information and communication & $0.8 \%$ \\
\hline Business related activities*** & $17.2 \%$ \\
\hline Education & $9.4 \%$ \\
\hline Health care & $1.1 \%$ \\
\hline Social work activities & $6.0 \%$ \\
\hline Art, Entertainment and Recreation & $0.9 \%$ \\
\hline Other service activities & $0.6 \%$ \\
\hline Total & $100 \%$ \\
\hline
\end{tabular}

"Repair of computers and personal and household goods and other personal service activities. *k* Services including finance and insurance, real state, professional, scientific and technical services, and administrative support activities.

Source: Continuous Sample of Working Histories (2017) and own calculations using NACE rev2 industry classification.

\subsection{Methodology}

As mentioned in the introduction, we designed a three-step methodology. In the first stage, we identified the effects of Social Economy companies in terms of social utility on territorial and social cohesion. In the second stage, we analysed whether there was a significantly different 
behaviour between SMkE companies and a control group, and quantified those effects using impact analysis techniques. Finally, the specific contributions to social and territorial cohesion identified in the previous stage were translated into monetary terms. In this section, we will describe each of the stages (a detailed analysis can be found in CEPES, 2019) and in the next section, we apply this methodology to the Spanish case.

\section{First stage: Identification and description of the effects of social utility upon territorial and social cohesion}

A key aspect of the impact analysis conducted is the correct, detailed identification of the effects that SE have in terms of social utility based on the revision of the theoretical and applied literature regarding social utility and the role of SE companies in society. This conceptual framework was used regardless of the fact that there were specific effects whose particularities do not permit their economic assessment with the current statistical information available, or, in case of feasibility, the assessment relies on a significant degree of subjectivity, as in the case of intangible effects. In this respect, in order to facilitate the quantification of the effects, we classified them from a triple perspective. Firstly, the effects can be direct or indirect; the latter when they account for costs that would have been generated without the presence of social economy entities. Secondly, social utility effects have an impact on different actors in society that need to be identified: employees, immediate environment (family and friends, F\&F), employers, public sector and society as a whole. Finally, for monetary value purposes, two additional differentiations must be carried out: effects can be considered tangible -if the possibility of objective economic measurement exists- and intangible - if the measurement is more complex and/or it is subject to subjective criteria-, and they can be seen as profit or cost. Table 3 summarizes the effects ${ }^{3}$ identified, which are aggregated in terms of social cohesion, in particular we defined four sub-categories, and territorial cohesion, in which we created three sub-categories, even though some of the effects can be considered as transversal to both dimensions.

3. A more detailed description of the effects can be found at Martínez et al (2013), chapter two (pp. 45). 


\section{Table 3. Effects of SMkE companies' activity on social and territorial cohesion}

Social cohesion

1. Creation of inclusive employment

Higher employment of groups of workers with specific employment difficulties: women over 45; people over 55, those with disabilities, at risk of social exclusion or with low qualifications.

\section{Higher levels of job stability} Higher stability in contracts, more employment episodes (in number and duration) and fewer unemployment episodes.
Territorial cohesion

1. Creation of economic activity and employment in the rural areas Rural entrepreneurship, generation of economic activity in rural areas.

\section{Competitiveness of the rural} economy.

Diversification of economic activity, production structure adjusted to rural strengths and needs.

\section{Lower wage gap}

Wage levels are more equal within SE entities.

\section{Higher levels of equality}

Diversity in management, equal labour conditions

and career paths, and higher possibilities of

reconciling a better family and professional life.

\section{Expansion of the private supply of social services \\ Contribution to economic activity in key social activities. Productive specialization of SMkE in dependence and care services and education.}

Source: The authors.

\section{Second stage: Assessment of differential behaviour}

The quantification of the effects identified from a theoretical perspective was based on impact analysis counterfactual techniques for simulation exercises, which permits comparison of a group exposed to a treatment (Social Market Economy) with a group in which there is absence of that treatment (profit-oriented firms). In our case the objective was to compare the situation of firms, and their workers, exposed to the treatment of "pertaining to social economy, and thus, affected by the distinguishing principles that characterize those entities" with the control group entities that were not exposed to the treatment (limited liability companies and corporations). In particular, we used a quasi-experimental approach to the impact analysis as firms and their workers were not randomly assigned to social economy or traditional profit-oriented firms.

In this stage, we tested our main working hypothesis: SMkE entities show differences in their behaviour in comparison to traditional profit-oriented firms (in terms of the differences identified in the previous stage). The impact analysis methodology provided results that identified the differences that are statistically significant, for which we first conducted non-parametric (Chi-Square test) statistical tests of independence between the groups' behaviour for each effect identified. 
The characteristics of the employers and employees pertaining to each of the two groups analysed showed an initial picture of the differences between SMkE and traditional profit-oriented firms and the contribution of SMkE in terms of social and territorial cohesion. In the second step, the results of the comparison of the real situation of SMkEs and alternative behaviour when considered to be traditional firms, in terms of number of workers and their characteristics, were used as a quantification of the values shared by SMkEs in terms of number of jobs lost, modifications in labour conditions and changes in the productive structure, specially affecting rural areas.

The alternative scenario constructed had some limitations in terms of the effects excluded from the same due to difficulties in quantifying them and/or in summarizing them in terms of loss of firms or jobs. These limits are linked to the theoretical difficulty in quantifying the intangible costs and benefits and to the possible lack of adequate statistical information.

\section{Third stage: Monetary assessment}

In order to estimate a global value for the contribution of SMkE to society and to have that estimation in monetary units, the effects on social and territorial cohesion were considered combining the results from the simulation with external sources of data, especially in terms of social security information (such as labour benefits, aid programs and services, pensions, subsidies) and tax information (such as tax rates). In this regard, for each of the seven categories in the previous section, only the differences that were statistically significant were translated into monetary terms.

The use of external sources of data, and its combination with the employment information in the database used requires some working hypotheses. The main ones are:

- The simulation is not based on the elimination of the activity conducted by SMkE firms, but the elimination of their behaviour as SE type entities, by substituting it with average behaviour observed in traditional profit-oriented firms (by economic sector and size) in terms of social and territorial cohesion effects previously defined.

- In order to measure the effects associated with the sectoral specialization of the SMkE firms (activities related to dependency, social services and education) and with their greater relative presence in the rural area, the exercise carried out consists of comparing the presence of the social economy in these activities with its average presence in the economy as a whole.

- The characterization of situations is based on mean values (or median if mean lack representativeness), such as average wages (with the higher possible level of desegregation for each group/category considered) to estimate the increase in income mentioned as a social cohesion effect.

- In order to contemplate the diverse aspects related to each type of firm included in the SMkE calculations are made at the maximum level of disaggregation in that respect, and then aggregated. The same criterion is applied to specific groups of workers and contracts subject to public policies in terms of aid (subsidies, cost-reducing policies, etc.). 
- There are effects with important intersection areas, overlapping as regards the beneficiaries or areas affected. These intersections were taken into account in the economic assessment to avoid duplication in the calculations.

Taking the first effect described for social cohesion as an example, it focuses on the employment of people with difficulties to access the labour market, such as people with disabilities. The comparison of SMkE and the control group indicates the difference in the proportion of workers with disabilities in each group. Applying the share of control group to SMkE gives the contribution of these entities that would be lost if they behaved like ordinary firms. That loss can be interpreted as the contribution of the social values of SMkE. Thus, for the particular example, in terms of employees and their immediate environment, the net profit is the value of the net wages that would not exist if SMkE behaved like traditional profit-oriented firms. In terms of employers, the public policies (wage cost-reducing policies, subsidies, etc.) associated with the employment of workers with disabilities can be considered to be benefits for the entities, and the higher number of workers with disabilities employed by SMkE entities translates into a net benefit. Finally, the net benefits for the public sector arise from the contributions to social security, tax related revenues and the decrease in pensions, net for the cost of public policies.

\section{Results}

The methodology described was used to analyse the case of the Social Market Economy in Spain. The first stage was conducted to adapt the theoretical identification of the effects to the specific case of Spain. The outcome of this identification is not included due to space constraints, but it is implicitly included in the data reported in the second stage in section 4.1. Once the specific considerations are shown, we analyse each of the seven categories of effects using the sample for Social Market Economy (SMkE) and the control group (CG).

The results obtained for the three stages are summarized in the following subsections, and allow us to accept our working hypothesis: SMkE firms show different behaviour to traditional profit-seeking firms (CG), which generates social value in terms of social and territorial cohesion, in several ways.

\subsection{Second stage: Assessment of differential behaviour. Step 1: Contrafactual analysis}

\subsubsection{Social cohesion}

1. Creation of inclusive employment. SMkE employs, to a much greater extent than the traditional profit-oriented firms, groups of workers with specific difficulties in accessing employment such as women over 45 , people over 55 , people with disabilities, people in situations or 
at risk of social exclusion and people with low qualifications, this differential being the main contribution made by SMkE firms to social cohesion.

As we can see (Table 4), percentages in SMkE are higher than in CG, thus $20.3 \%$ of women over 45 are employed in SMkE while in CG this percentage is $14.0 \%$. Higher mean percentages of total employment in each firm are also seen in workers between 45 and 54 years old (25.8\% compared to $23.1 \%$ ) and in workers over 55 (18.7\% compared to $14.8 \%)$. In the case of workers with disabilities, the mean percentage of total employment of each firm was much higher in SMkE firms (15.3\%) than in CG (1.3\%), especially for workers with higher degrees of disabilities (equal to or over 65\%).

Table 4. Contribution of Social Market Economy (SMkE) and Control Group (CG) to the creation of inclusive employment. Percentage of total employment of each group and mean percentage of total employment in each firm

\begin{tabular}{lcc} 
& SMKE & CG \\
\hline $\begin{array}{l}\text { Women } 45 \text { years old and over. Percentage of total employment of each } \\
\text { group }\end{array}$ & $20.2 \%$ & $14.0 \%$ \\
\hline $\begin{array}{l}\text { Between } 45 \text { and } 54 \text { years old } \\
55 \text { years old and over }\end{array}$ & $12.1 \%$ & $9.4 \%$ \\
\hline $\begin{array}{l}\text { Workers between } \mathbf{4 5} \text { and } 54 \text { years old. Mean percentage of total } \\
\text { employment of each firm. }\end{array}$ & $25.8 \%$ & $23.1 \%$ \\
\hline $\begin{array}{l}\text { Workers } 55 \text { years old and over. Mean percentage of total employment of } \\
\text { each firm. }\end{array}$ & $18.7 \%$ & $14.8 \%$ \\
\hline $\begin{array}{l}\text { Workers with disabilities (degree of disability over 33\%). Mean percentage } \\
\text { of total employment in each firm. }\end{array}$ & $15.8 \%$ & $1.3 \%$ \\
\hline Distribution of workers with disabilities by degree & & \\
\hline Between $33 \%$ and 65\% & $81.3 \%$ & $87.2 \%$ \\
\hline $\begin{array}{l}\text { Equal or over 65\% } \\
\text { Total }\end{array}$ & $18.7 \%$ & $12.8 \%$ \\
\hline
\end{tabular}

Source: Continuous Sample of Working Histories (2017) and own calculations.

2. Higher levels of job stability. SMkE promotes greater stability in contracts. We obtained the following results by using information regarding working lives during the last 10 years, from 2009 to 2018, (Table 5):

a) Although average length of analysed professional trajectories is lower in SE than in profit-oriented economy, it seems that SE employment is more stable: $48.3 \%$ of SMkE workers have had one or more continuous job experiences (without being unemployed) 
in the analysed period compared to $36.7 \%$ in capitalist firms that form part of the control group.

b) The average number of employment episodes also confirms a higher stability in SMkE workers' working lives (4.6 employment episodes for every 10 years versus 9.1 episodes in CG).

c) Consistent with the previous point, the average duration of employment episodes is also higher in SMkE than in the control group.

d) As a consequence of its higher employment stability, SMkE workers had less unemployment episodes with contributory benefits and these episodes had a lower average length.

\section{Table 5. Working histories of paid workers. Social Market Economy (SMkE) and Control Group (CG)}

\begin{tabular}{lrr} 
& SMkE & CG \\
\hline Sample size (no of workers) & 9,659 & 9.553 \\
\hline Avge. length (years) of analysed working histories & 5.8 & 8.4 \\
\hline Employment and Unemployment Episodes & & \\
\hline Workers with continuous employment episodes (\% over total of workers) & $48.3 \%$ & $36.2 \%$ \\
\hline $\begin{array}{l}\text { Workers with one or more unemployment episodes with benefits } \\
\text { (\% over total of workers) }\end{array}$ & $28.5 \%$ & $42.0 \%$ \\
\hline Avge. of employment episodes (№ in 10 years) & 4.6 & 9.1 \\
\hline Avge. length (years) of employment episodes & 3.9 & 3.6 \\
\hline Avge. of unemployment episodes with benefits (№ in 10 years) & 2.4 & 4.0 \\
\hline Avge. length (months) of unemployment episodes with benefits & 1.4 & 1.9 \\
\hline
\end{tabular}

(1) Workers in insertion companies and special employment centres are not included

Source: Continuous Sample of Working Histories (2017) and own calculations.

3. Lower wage gap. Salary levels are more even within SMkE firms than in the control group (Table 6). The lower salary dispersion is mainly due to greater numbers of highly qualified workers. Thus, in the SMkE firms, the average wage of highly qualified workers (group 1: engineers, university graduates, top management and group 03: Head of administration and factory) was higher than the average for global salary by $65 \%$ for group 1 , and by $71 \%$ for group 3 , while in the control group these differences were $102 \%$ and $110 \%$, respectively. 
Table 6. Wage ratios of full-time workers by personal and job characteristics. Social Market Economy (SMkE) and Control Group (CG), 2017 Differences in regard to total average wage in each group, index (group average wage=100).

\begin{tabular}{|c|c|c|}
\hline & SMkE & CG \\
\hline Total & 100 & 100 \\
\hline Men & 103 & 107 \\
\hline Women & 95 & 90 \\
\hline \multicolumn{3}{|l|}{ Age group } \\
\hline Up to 25 years old & 62 & 67 \\
\hline $25-44$ years old & 96 & 98 \\
\hline 45-54 years old & 103 & 109 \\
\hline 55 or more years old & 106 & 100 \\
\hline \multicolumn{3}{|l|}{ Worker's degree of disability } \\
\hline With disabilities (33\%-65\%) & 80 & 84 \\
\hline With disabilities ( $\geq 65 \%$ ) & 111 & 81 \\
\hline \multicolumn{3}{|l|}{ Qualification group } \\
\hline 01. Engineers, university graduates, top management & 165 & 202 \\
\hline 02. Technical engineers and qualified assistants & 146 & 132 \\
\hline 03. Head of administration and factory & 171 & 210 \\
\hline 04. Non-qualified assistants & 107 & 138 \\
\hline 05. Clerical workers & 119 & 123 \\
\hline 06. Subordinates & 70 & 86 \\
\hline 07. Assistant clerical workers & 96 & 74 \\
\hline 08. 1st and 2nd degree tradesmen & 91 & 97 \\
\hline 09. 3rd class tradesmen and specialists & 78 & 80 \\
\hline 10. Labourers and similar & 66 & 65 \\
\hline \multicolumn{3}{|l|}{ Type of contract } \\
\hline Indefinite-term & 106 & 103 \\
\hline Fixed-term & 71 & 74 \\
\hline \multicolumn{3}{|l|}{ Residence of worker } \\
\hline Urban & 106 & 107 \\
\hline Rural & 95 & 94 \\
\hline \multicolumn{3}{|l|}{ Nationality of worker } \\
\hline National & 103 & 105 \\
\hline Foreign & 76 & 78 \\
\hline
\end{tabular}

Note: Wages in The Basque Country and the Navarre region are not included. Only workers who worked full time all of 2017 are included.

Source: Continuous Sample of Working Histories (2017) and own calculations. 
4. Higher levels of equality. This is shown by the better results obtained in different dimensions the same as the gender wage gaps, which are clearly smaller; diversity in management, with greater incorporation of women and people with disabilities (Table 7); and the possibilities of reconciling a better family and professional life.

Table 7. Diversity in high qualification jobs and top management. Social Market Economy (SMkE) and Control Group (CG). 2018. Percentage of different groups of the total qualification Group 01 contribution

\begin{tabular}{lrr} 
& SMkE & CG \\
\hline Women & $51.0 \%$ & $44.8 \%$ \\
\hline Women $25-34$ years old & $32.1 \%$ & $29.7 \%$ \\
\hline Workers with disabilities $>33 \%$ & $3.6 \%$ & $0.3 \%$ \\
\hline 55 or more years old & $16.0 \%$ & $16.5 \%$ \\
\hline Up to 25 years old & $1.2 \%$ & $1.4 \%$ \\
\hline Foreign workers & $3.8 \%$ & $12.0 \%$ \\
\hline
\end{tabular}

Note: Partners in the Special tax regime for self-employed workers (RETA) are not included.

Source: Continuous Sample of Working Histories (2017) and own calculations.

5. Expansion of the private supply of social services. The productive specialization of the SMkE in services linked to dependence and care of the elderly and disabled is significant, as well as in educational services (Table 8). Thus, while SMkE represents $2.1 \%$ of the total economy, its supply of social services (elderly, disabled, dependence...) is much higher $(8.1 \%)$. In the case of other care activities, this percentage is also higher (7.7\%). 
Table 8. Share of SMkE firms with economic activities linked to social services (Activities for the elderly and disabled and other care activities). Percentage of the total for each economic activity, 2017

SMkE

\begin{tabular}{lr}
\hline Activities for the elderly and disabled & $\mathbf{8 . 1 \%}$ \\
\hline 871. Residential nursing care activities & $\mathbf{2 . 4 \%}$ \\
\hline $\begin{array}{l}\text { 872. Residential care activities for mental illness, mental health and substance } \\
\text { abuse }\end{array}$ & $6.1 \%$ \\
\hline 873. Residential care activities for the elderly and disabled & $1.7 \%$ \\
\hline 881. Social work activities without accommodation for the elderly and disabled & $17.2 \%$ \\
\hline Other care activities & $\mathbf{7 . 7 \%}$ \\
\hline 879. Other residential care activities & $7.8 \%$ \\
\hline 889. Other social work activities without accommodation & $7.7 \%$ \\
\hline Total economy & $\mathbf{2 . 1 \%}$ \\
\hline
\end{tabular}

Source: Continuous Sample of Working Histories (2017) and own calculations using NACE rev2 industry classification.

\subsubsection{Territorial cohesion}

The analysis confirms the greater relative presence of the Social Market Economy (SMkE) in medium-sized cities and rural areas; these results indicate a significant contribution to the creation of business and employment, to the competitiveness of local economies and to the resilience of the population in these areas:

1. Rural location. Creation of economic activity and employment in rural areas. SMkE has important effects on the rural economy in terms of creation of economic activity and employment.

a) The SMkE is mostly located and in municipalities with fewer than 40,000 inhabitants: $60.2 \%$ of companies and $54.6 \%$ of their workers (Graph 2$)^{4}$. In traditional profit-oriented firms, these percentages are inverted and both they and their workers are mostly located in the urban environment.

4. It should be noted that one of the stratification criteria for the design of the control group was industry specialization and thus, in order to compare differences in industry specialization we must design a new control group. In particular, we compare our SMkE group with a control group formed by all private profit-oriented firms included in the CSWH sample, excluded self-employment ones, that we denote as "capitalist economy". 
Graph 2. Company location and workers 'place of residence by geographical area (Urban or rural). SMkE and Capitalist economy (CG). Percentage of total

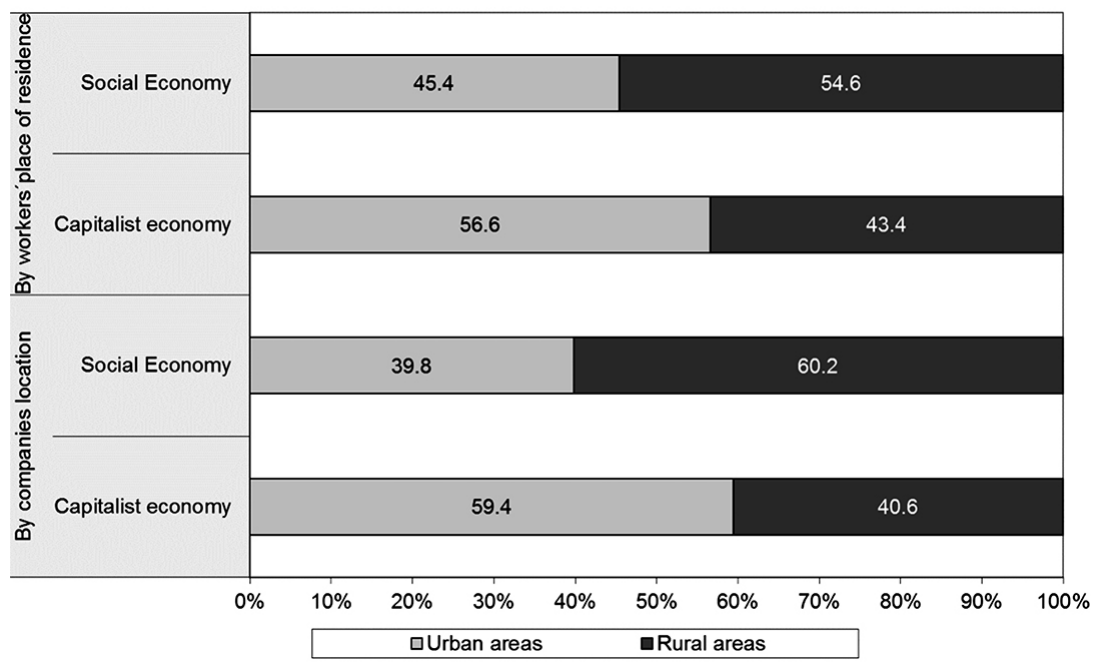

Source: Continuous Sample of Working Histories (2017) and own calculations.

b) The SMkE contribution to medium-sized cities and rural areas is also channelled through entrepreneurship. If only the youngest companies are considered, $47.4 \%$ of SMkE companies are located in medium-sized cities and rural areas and $52.6 \%$ in large cities. In the case of the capitalist economy, these percentages are $35.8 \%$ and $64.2 \%$ respectively (Graph 3). 


\section{Graph 3. Distribution of new firms by type of area. SMkE and Capitalist economy, percentage of total number of new firms}

SMkE

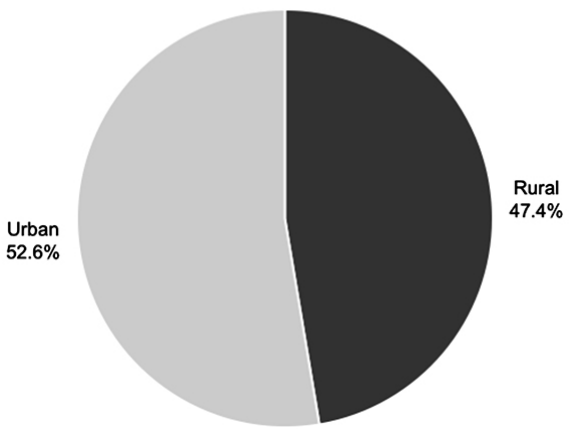

Capitalist economy

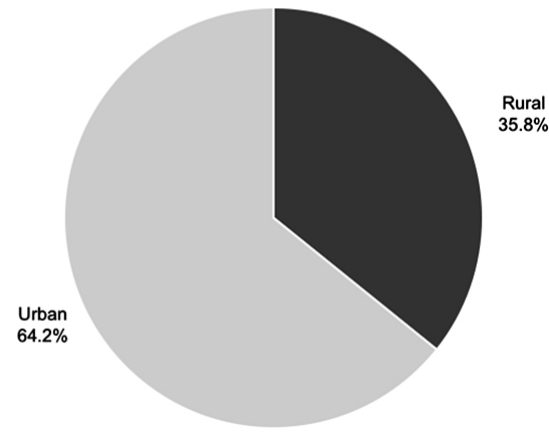

Source: Continuous Sample of Working Histories (2017) and own calculations.

2. Competitiveness of the rural economy. Diversification of economic activity, production structure adjusted to rural strengths and needs. The sectorial distribution of SMkE companies also shows greater dispersion, thus favouring the diversification of the rural economy. It improves the competitiveness of rural economies through the development of certain industries that permit better use of potential or bring a supply of social and educational services that is vital to stopping the loss of population. The importance of the SMkE in the agri-food industry stands out, also, in education and in dependency services (Table 9). 
Table 9. Distribution by economic sector in rural areas. Social Economy (SMkE) and Capitalist economy. Percentage of total economic activity, 2018

\begin{tabular}{lcr}
\hline Agriculture, forestry and fishing & SMkE & $\begin{array}{r}\text { Capitalist } \\
\text { economy }\end{array}$ \\
\hline Manufacturing & $25.8 \%$ & $7.8 \%$ \\
\hline Energy, water supply, waste management & $26.9 \%$ & $24.6 \%$ \\
\hline Construction & $0.6 \%$ & $0.9 \%$ \\
\hline Wholesale and retail trade and personal services* & $4.7 \%$ & $11.6 \%$ \\
\hline Transport, storage and post services & $17.0 \%$ & $22.8 \%$ \\
\hline Accommodation and Food Service Activities & $3.1 \%$ & $6.4 \%$ \\
\hline Information and communication & $2.1 \%$ & $9.2 \%$ \\
\hline Business related activities*** & $0.5 \%$ & $1.0 \%$ \\
\hline Education & $7.0 \%$ & $8.4 \%$ \\
\hline Health care & $6.4 \%$ & $2.0 \%$ \\
\hline Social work activities & $0.5 \%$ & $1.2 \%$ \\
\hline Art, Entertainment and Recreation & $3.1 \%$ & $1.9 \%$ \\
\hline Other service activities & $1.1 \%$ & $1.5 \%$ \\
\hline Total & $1.2 \%$ & $0.7 \%$ \\
\hline Standard deviation & $100 \%$ & $100 \%$ \\
\hline
\end{tabular}

"Repair of computers and personal and household goods and other personal service activities. ** Services including Financial and insurance, real state, professional, scientific and technical services and administrative support activities.

Source: Continuous Sample of Working Histories (2017) and own calculations using NACE rev2 industry classification. 


\subsection{Second stage: Assessment of the differential behaviour. Step 2: in terms of employment and labour conditions}

Once the differences were identified, we proceeded to estimate the social value added by SMkE firms, by simulating the "loss" if they behaved like traditional profit-oriented firms, losing their principles and thus, the social value associated with them, as defined previously through social and territorial cohesion. The estimation resulted in a quantification of the values shared by SMkE in terms of number of jobs lost, modifications in labour conditions and changes in the productive structure especially affecting rural areas.

\subsubsection{Social Cohesion}

The impact of the principles of the Social Market Economy, and what would happen if it behaved like the control group, are summarised in the following points (see Table 10)

1) Creation of inclusive employment. More than 172,000 workers belonging to a group with difficulty accessing the occupation would lose their jobs. Of these, 86,266 would be people with disabilities; 58,553 low-skilled workers; 21,201 over 55 years; 3,436 people in a situation of social exclusion and 3,027 women over 45 years.

2) Higher levels of jobs stability. Nearly 125,000 workers who enjoyed continuous periods of employment in the Social Market Economy would have one or more episodes of unemployment. Of these, more than half would be self-employed (shareholder employee of Social Market Economy companies).

3) Higher levels of equality. A smaller number of workers would be expelled from management positions and positions requiring high qualifications. More than 1,600 workers usually underrepresented in the highest positions of the companies would stop occupying these positions (about 1,100 women and 600 people with disabilities).

More than 2,600 workers who currently (in the specific year analysed) enjoy leave of absence for the care of ascendants or descendants would not opt for that leave.

4) Expansion of the private supply of social services and education. If the SMkE had the same sectorial specialization as the control group, the supply of assistance to persons in a situation of dependence and other social services would be reduced and these activities would have 9,000 fewer employed people. Furthermore, the number of people employed in the private supply of educational services would be reduced by 20,000 workers, significantly affecting both the level and diversity of the supply within these activities.

5. In this stage the contribution of SMkE to social cohesion in terms of more equal wages is not directly estimated in terms of workers affected. Wages are used in the following stage of monetarization. 
Table 10. Contribution of SMkE's principles to social cohesion. Impact recorded in number of people.

CONTRIBUTION TO SOCIAL COHESION № of persons

1. Occupation of groups with difficult access to employment ( $n-0$ of workers who would lose their jobs)

172,483

Workers with disabilities 86,266

Workers at risk or in a situation of social exclusion 3,436

Workers over 55 (without disabilities) 21,201

Women over 45 (up to 55 and without disabilities) 3,027

Workers with low qualifications (not considered in the previous groups)

58,553

2. Employment quality (not considering previous groups) (no of workers whose working conditions would be modified)

Employment stability 124,921

Self-employment (partner in a society) 66,339

Paid employment (without unemployment interruptions) 58,581

3. Equal opportunities ( $n$ 으 of workers whose working conditions would be modified)

High qualifications and top management 1,672

Women 1,091

Workers with disabilities $>33 \%$

Parental and care related leaves 2,604

4. Supply of social and educational services ( $n$ - of workers who would lose their jobs in these sectors)

Dependence and care services and other social work activities

Education 20,615

Source: Continuous Sample of Working Histories (2017) and own calculations. Data for January 2018.

\subsubsection{Territorial Cohesion}

In the territorial area, about 55,000 jobs would be lost in rural areas and small cities ${ }^{6}$ (Table 11). Loss is important in quantitative terms but also in qualitative terms as almost $50 \%$ of

6. We define "rural areas and medium-sized cities" as those with less than 40,000 inhabitants. 
these jobs $(23,322)$ are carried out by women, more than 20,000 by people with medium and high level qualifications and more than 5,000 by people with disabilities. On the other hand, entrepreneurship in rural areas provides employment to 1,244 people, those that would soon leave work (under 3 years) in Social Market Economy companies.

There is a specialization of SMkE in rural areas, especially in those sectors closely linked to population maintenance such as social work activities and education. If these companies behaved like capitalist firms, 23,000 jobs would be lost from the private supply of these activities in rural areas. About 141,000 people would have to move to urban areas.

Table 11. Contribution of SMKE's principles to territorial cohesion. Im-
pact recorded as number of people

\begin{tabular}{lr} 
& № of people \\
\hline 1. Impact on rural employment (no of workers that would lose their jobs*) & 54,236 \\
\hline Women & 23,322 \\
\hline Up to 25 years old & 2,332 \\
\hline 55 or more years old & 10,196 \\
\hline Workers with disabilities & 5,044 \\
\hline Medium and high qualifications & 20,067 \\
\hline General certificate of education, vocational training & 11,661 \\
\hline Technical higher education & 3,091 \\
\hline Graduates and undergraduates & 5,315 \\
\hline Entrepreneurship in rural areas & 1,244
\end{tabular}

\section{Competitiveness of the rural economy}

Productive diversification for a better adaptation of population needs

23,240

Dependence and care services and other social work activities

15,031

Education

8,209

Productive structure more suitable to potentialities and needs

N.A.

* In this category, the total of 54,236 persons serves as a reference of the net amount of people affected, while subcategories accounts for the gross amount of people affected by each of them and thus, for instance, women with disability will be considered in the two subcategories separatelly.

Source: Continuous Sample of Working Histories (2017) and own calculations. Data from January 2018. 


\subsection{Third stage: Monetary assessment}

In this last stage, the effects identified and quantified in the previous stages are translated into monetary terms combining that information with external database sources, mainly tax related as mentioned in the methodology subsection.

In the previous phase, we analysed the impacts of SMkE values from a double perspective that includes its potential contribution to both social and territorial cohesion. In this stage, whose main objective is to advance in the monetization of these effects, the two perspectives are joined in order to avoid double accounting (e.g. the employment of a person over 55 years of age in rural areas is assessed only once). Furthermore, most of the monetized effects are linked to social cohesion due to the methodological difficulties in quantifying the positive effects on rural economies (beyond the creation of inclusive employment).

In this phase, the distinction between direct and indirect benefits is introduced, which is usual in the estimation of costs and benefits linked to a certain phenomenon or reality.

In monetary terms, the Social Market Economy contributes 6,229 million Euros per year in benefits to society, 3,930 million Euros per year in salaries for groups with difficult employability and 1,770 million Euros per year in benefits for Public Administrations (Table 12). By agents, the main beneficiaries are the groups with the greatest difficulties in accessing employment, which receive 3,930 million Euros per year in salaries. Second, there is Public Administration, with 1,770 million Euros per year of direct and indirect benefits (expenses not incurred) and, finally, the companies themselves, which obtain a net benefit of about 528 million Euros per year 
Table 12. Total benefits of the contribution of SMkE companies (million Euros for 2018)

\begin{tabular}{|c|c|c|c|c|c|}
\hline & Household & Firms & $\begin{array}{l}\text { Public } \\
\text { sector }\end{array}$ & Total & $\%$ \\
\hline 1. DIRECT BENEFITS & $3,930.3$ & 373.8 & $1,231.2$ & $5,535.4$ & 88.9 \\
\hline $\begin{array}{l}\text { A. Creation of inclusive employment } \\
\text { and rural employment }\end{array}$ & $3,208.3$ & 373.8 & 881.6 & $4,463.8$ & 71.7 \\
\hline Workers with disabilities & $1,406.5$ & 370.9 & -17.0 & $1,760.4$ & 28.3 \\
\hline $\begin{array}{l}\text { Workers at risk or in situation of } \\
\text { social exclusion }\end{array}$ & 70.3 & 2.9 & -0.2 & 73.0 & 1.2 \\
\hline $\begin{array}{l}\text { Workers } 55 \text { or more years old } \\
\text { (without disabilities) }\end{array}$ & 396.1 & n.a & 222.4 & 618.6 & 9.9 \\
\hline $\begin{array}{l}\text { Workers with low qualifications (not } \\
\text { considered in the previous groups) }\end{array}$ & 707.9 & n.a & 355.4 & $1,063.4$ & 17.1 \\
\hline $\begin{array}{l}\text { Women over } 45 \text { years old (not } \\
\text { considered in the previous groups) }\end{array}$ & 59.5 & n.a. & 37.4 & 96.9 & 1.6 \\
\hline $\begin{array}{l}\text { Other workers in rural area (not } \\
\text { considered in the previous groups) }\end{array}$ & 567.8 & n.a. & 283.4 & 851.2 & 13.7 \\
\hline B. Higher levels of job stability & 702.7 & n.a. & 349.5 & $1,052.3$ & 16.9 \\
\hline C. Higher levels of equality & 19.3 & n.a. & n.a. & 19.3 & 0.3 \\
\hline 2. INDIRECT BENEFITS & n.a. & 154.9 & 539.1 & 694.0 & 11.1 \\
\hline $\begin{array}{l}\text { A. Creation of inclusive employment } \\
\text { and rural employment }\end{array}$ & n.a. & n.a. & 512.1 & 512.1 & 8.2 \\
\hline B. Higher levels of job stability & n.a. & 154.9 & 27.0 & 181.9 & 2.9 \\
\hline C. Higher levels of equality & n.a. & n.a. & n.a. & n.a. & n.a. \\
\hline TOTAL BENEFITS & $3,930.3$ & 528.7 & $1,770.3$ & $6,229.4$ & 100.0 \\
\hline
\end{tabular}

Source: Continuous Sample of Working Histories (2017) and own calculations. n.a: no available data.

\section{Conclusions}

The Social Economy is acknowledged as an important actor in the pursuit of sustainable development and decent work (Borzaga et al., 2017), but despite this increasing interest in the contribution of the Social Economy to the current and future challenges the world faces, there is still a deficit in terms of adequate quantitative indicators that reinforce the message of the 
potential that the Social Economy has in terms of its contribution to sustainable and inclusive development. The complexity in the delimitation of the Social Economy, especially in operating terms, as well as the need to correctly measure the impact of the activity of the firms pertaining to the Social Economy is crucial for its assessment at a social and political level.

This research contributes to understanding the global contribution of the Social Economy, beyond the traditional aggregated measures based on national accounting variables. The focus on the concept of social utility, in terms of social and territorial cohesion, contributes to a more accurate assessment of the potential contribution of the differentiating and intrinsic values that entities pertaining to the Social Economy have, which are compatible with the market-oriented activities they conduct, in comparison to traditional profit-oriented firms. In this sense, our results give empirical support to the acknowledge by the European Union of the key role of Social Economy, and in particular Social Market Economy, as a transformative agent of the economic activity (Bassi and Fabbri, 2020).

The results presented here show that the values and principles of SE influence the behaviour of its companies, which although operating with a clear market orientation and on equal terms with profit-oriented firms, unlike the latter, are capable of generating value for the whole of society through inclusive employment and the reduction of inequalities. This contribution would not exist if traditional profit-oriented firms, also market oriented, conducted those activities, especially in reference to labour inclusion and to working conditions, including equal opportunities of specific groups and the provision of specific services of special social interest. In this regard, SE contribution is directly connected to the Agenda 2020 promoted by the United Nations, and in particular to the Sustainable Development Goal 8: Promote inclusive and sustainable economic growth; employment and decent work for all (especially with the Target 8.5: by 2030; achieve full and productive employment and decent work for all men, including for young people and persons with disabilities; and equal pay for work of equal value). In addition, to the Sustainable Development Goal 10: Reduced inequalities within and among countries (especially with Target 10.2: By 2030, empower and promote the social, economic and political inclusion of all, irrespective of age, sex, disability, race, ethnicity, origin, religion or economic or other status).

These effects have been valued economically, amounting to 4 billion Euros annually, which would not exist if the activities were conducted by profit-oriented firms. Indeed, the number obtained can be taken as a lower threshold due to difficulties in the assessment of certain effects, such as those of an intangible nature. In this sense, this work confirms the contribution of the Social Market Economy in terms of the social value generated, with a positive impact on social and territorial cohesion, implicit objectives of an inclusive and sustainable growth agenda, with a people-centred growth approach. In this sense the results support the narrative of the key role of Social Market Economy as a transformative agent of the productive system and the need for public policies supporting Social Economy entities (Chavez and Gallego-bono, 2020).

For future research, it is of special concern to advance in the economic assessment of the effects related to social cohesion, as one of the main constraints observed is the lack of statistical information. It is equally important to advance in a more accurate identification of the 
effects related to territorial cohesion due to their complexity. From a methodological perspective, there are alternative approaches to the construction of the control group that should be considered in a robustness exercise. All the foregoing will contribute to a more accurate dimensioning of the generation of social utility, which is the main asset of social economy in view of the activity developed by other types of enterprises.

\section{References}

ARENA, M., AZZONE, G. and BENGO, I. (2015): Performance Measurement for Social Enterprises, Voluntas, 26: 649-672. https://doi.org/10.1007/s11266-013-9436-8.

ARVIDSON, M., LYON, F., MCKAY, S. and MORO, D. (2013): Valuing the social? The nature and controversies of measuring social return on investment (SROI), Voluntary Sector Review, 4 (1), 3-18. DOI: https://doi.org/10.1332/204080513X661554.

BARRAKET, J. and YOUSEFPOUR, N. (2013): Evaluation and social impact measurement amongst small to medium social enterprises: process, purpose and value, Australian Journal of Public Administration, 72(4): 447- 458. DOI 10.1111/1467-8500.12042.

BASSI, A. and FABBRI, A. (2020): Under pressure: Evolution of the social economy institutional recognition in the EU, Annals of Public and Cooperative Economics, 91(3), 411-433. https://doi. org/10.1111/apce.12264

BEN-NER, A. (2018): Reflections on the future evolution of social, nonprofit and cooperative enterprise, Annals of Public and Cooperative Economics, 89, 109-124. D0I: http://dx.doi. org/10.1111/apce.12196.

BIRCHALL, J. and KETILSON, L.H. (2009): Resilience of the Cooperative Business Model in times of crisis. International Labor Organization: Geneva, Switzerland.

BORZAGA, C.; SALVATORI, G. and BODINI, R. (2017): Social and Solidarity Economy and the Future of Work. International Labor Organization: Geneva, Switzerland.

BROWN, L., HICKS, E. and LECLERC, A. (2015): The Sustainability and planning scorecard: A tool designed for and with local retail food co-operatives. In: Brown et al., Co-operatives for Sustainable Communities: Tools to Measures Co-operative Impact and Performance, 87-117. 0ttawa: Co-operatives and Mutuals Canada.

CALDERÓN, B. and CALDERÓN, M.J. (2012): La calidad del empleo de las entidades de la economía social en periodo de crisis, Ekonomiaz, 79. 
CASTRO NUÑEZ, R; BANDEIRA, P. and SANTERO-SANCHEZ, R. (2020): The Social Economy, Gender Equality at Work and the 2030 Agenda: Theory and Evidence from Spain, Sustainability, 12(12), 5192. D0I: 10.3390/su12125192.

CEPES (2019): Análisis del impacto socioeconómico de los valores y principios de la Economía Social en España, Confederación Empresarial Española de la Economía Social (CEPES), Madrid.

CHAVES-AVILA, R. and GALLEGO-BONO, J.R. (2020): Transformative Policies for the Social and Solidarity Economy: The New Generation of Public Policies Fostering the Social Economy in Order to Achieve Sustainable Development Goals. The European and Spanish Cases. Sustainability, 12, 4059. D0I: 10.3390/su12104059.

CHRISTIANSON, R. (2015): The co-operative susteinability scorecard, en Brown et al., Co-operatives for Sustainable Communities: Tools to Measures Co-operative Impact and Performance, 80-86. Ottawa: Co-operatives and Mutuals Canada.

DÍAZ, M. and MARCUELLO, C. (2010): “Impacto económico de las cooperativas. La generación de empleo en las sociedades cooperativas y su relación con el PIB", CIRIEC-España, Revista de Economía Pública, Social y Cooperativa, 67, 23-44.

DUFOUR, B. (2015): State of the art in social impact measurement: methods for work integration social enterprises measuring their impact in a public context. 5th EMES International Research Conference on Social Enterprise: "Building a scientific field to foster the social enterprise eco-system", EMES, June 2015, Helsinki, Finland.

DUGUID, F. (2017): Non-Financial Tools and Indicators For Measuring The Impact Of Co-Operatives, Journal of Co-Operative Accounting and Reporting, 5(1), 40-54.

ETXEZARRETA, E., MENDIGUREN, J.C.P., DÍAZ, L. and ERRASTI, A. (2018): Valor social de las cooperativas sociales: aplicación del modelo poliédrico en la cooperativa para la acogida de menores Zabalduz S.Coop, CIRIEC-España, Revista de Economía Pública, Social y Cooperativa, 93, 155-180. DOI:10.7203/CIRIEC-E.93.9953.

EUROPEAN ECONOMIC AND SOCIAL COMMITEE (2016): Recent evolutions of the Social Economy in the European Union. CES/CSS/12/2016/23406. European Economic and Social Committee: Brussels, Belgium.

GADREY, J. (2006): L'utilité sociale en question, à la recherche de conventions, de critères de méthodes d'évaluation, In: Les dynamiques de l'économie sociale et solidaire, eds. Jean-Noël Chopart, Guy Neyret and Daniel Rault, 237-279. Paris: La Découverte, collection Recherches.

GIBBON, J. and DEY, C. (2011): Developments in Social Impact Measurement in the Third Sector: Scaling Up or Dumbing Down?, Social and Environmental Accountability Journal, 31:1, 6372, DOI: 10.1080/0969160X.2011.556399. 
GORDON, J. (2015): Understanding and measuring the benefits and impacts of Co-operatives, in Brown et al., Co-operatives for Sustainable Communities: Tools to Measures Co-operative Impact and Performance, 152-179. Ottawa: Co-operatives and Mutuals Canada.

GRAY, R. (2000): Current developments and trends in social and environmental auditing, reporting and attestation: a review and comment, International Journal of Auditing, 4(3), 247-268.

GUZMAN, C., SANTOS, F.J. and BARROSO, M.d.l.O. (2020): Cooperative essence and entrepreneurial quality: a comparative contextual analysis, Annals of Public and Cooperative Economics, 91: 95-118. DOI:10.1111/apce.12257.

HOUGH, P. (2015): Walking the talk: Putting co-operative principles and values into practice with the help of the Co-op Index, en En Brown et al., Co-operatives for Sustainable Communities: Tools to Measures Co-operative Impact and Performance, 118-128. Ottawa: Co-operatives and Mutuals Canada.

MAAS, K. and LIKET, K. (2011): Social Impact Measurement: Classification of Methods. In R. Burritt, S. Schaltegger, M. Bennett, T. Pohjola, \& M. Csutora (Eds.), Environmental Management Accounting and Supply Chain Management, 171-202.

MANETTI, G. (2014): The Role of Blended Value Accounting in the Evaluation of Socio-Economic Impact of Social Enterprises, Voluntas, 25, 443-464. https://doi.org/10.1007/s11266012-9346-1.

MARTÍNEZ, M.I., CASTRO, R.B., ALEMÁN, D., GUILLÓ, N. and SANTERO, R. (2013): El impacto socioeconómico de las entidades de economía social. Fundación EOI. Madrid.

MARTINEZ-LEON, I.M.; OLMEDO-CIFUENTES, I.; MARTÍNEZ-VICTORIA, M. and ARCAS-LARIO, N. (2020): Leadership Style and Gender: A Study of Spanish Cooperatives, Sustainability, 12, 5107. DOI: https://doi.org/10.3390/su12125107.

MEDEIROS, E. (2016): Territorial Cohesion: An EU concept, European Journal of Spatial Development, 60 .

MELIÁ-MARTÍ, E.; TORMO-CARBÓ, G. and JULIÁ-IGUAL, J.F. (2020): Does Gender Diversity Affect Performance in Agri-Food Cooperatives? A Moderated Model, Sustainability, 12, 6575. DOI:10.3390/su12166575.

PUBLIC HEALTH ENGLAND (2015): Local action on health inequalities. Using the Social Value Act to reduce health inequalities in England through action on the social determinants of health. Public Health England, London: UK.

RETOLAZA, J.L., SAN-JOSE, L. and RUIZ-ROQUEÑI, M. (2015): Monetarizing the social value: theory and evidence, CIRIEC-España, Revista de Economía Pública, Social y Cooperativa, 83, 43-62. 
RODET, D. (2008): Les définitions de la notion d'utilité sociale. Économie et Solidarités, 39 (1): 164-173.

ROMÁN CERVANTES, C., GUZMÁN PÉREZ, B., MENDOZA JIMÉNEZ, J. \& PÉREZ MONTEVERDE, M. V. (2020): La sostenibilidad social de las SATs: una propuesta de indicadores para su evaluación, REVESCO, Revista de Estudios Cooperativos, 133, e67336. https://doi.org/10.5209/ reve.67336.

SANTERO, R. and CASTRO, R. B. (2016): Análisis de las condiciones laborales en las entidades de Economía Social en España desde una perspectiva de género, REVESCO, Revista de Estudios Cooperativos, 121: 228-255. D0I: https://doi.org/10.5209/rev_REVE.2016.v121.51309.

TOMÁS CARPI, J. (2008): The Prospects for the Social Economy in a Changing World, CIRIEC-España, Revista de Economía Pública, Social y Cooperativa, 62, 7-33.

VANCLAY, F. (2003): International Principles for Social Impact Assessment, Impact Assessment and Project Appraisal, 21, 1: 5-12. D0I: 10.3152/147154603781766491.

VALIENTE, L. (2019): ¿Podría estar contribuyendo el cooperativismo a fijar la población en el territorio de Andalucía?, CIRIEC-España, Revista de Economía Pública, Social y Cooperativa, 97, 49-74. DOI: 10.7203/CIRIEC-E.97.13046. 